\title{
Research on Library Institution Reorganization of Military Academies
}

\author{
Lishu Zhang \\ Aviation University of Airforce \\ Changchun, China
}

\author{
Dake Wang \\ Aviation University of Airforce \\ Changchun, China
}

\author{
Lili Zhao \\ Aviation University of Airforce \\ Changchun, China
}

\begin{abstract}
This paper makes clear the new development ideas and tasks of military academies library on the basis of comprehensive environmental scanning and business analyzing. It puts forward the new organization framework, hoping that through the business reform, human resources integration and optimization, the library can improve the efficiency of the organization operation and achieve the sustainable development.
\end{abstract}

Keywords-military academies library; organization framework; business reform

\section{INTRODUCTION}

"The library is a living organism", Ranganahan, a library scientist in India, said in his famous book "The five law of Library Science" .In order to adapt to the change of internal and external environment, the adjustment of Library's various elements to achieve better organizational goals is an inevitable move for libraries to survive and develop as an organization. The reform and adjustment of this organization is an active behavior for library to change its concept and seek development. At present, facing the application and popularization of new technology, the transformation of academic research and communication mode, and the change of users' information needs and behaviors, university libraries has to transform, innovate the organizational structure and rebuild service processes, so that they can better move towards the future.

\section{UNIVERSITY LIBRARY ORGANIZATION CHANGE PRACTICE}

The first stage: at the beginning of the founding of military academy, the library was small, the division was not very fine, the library departments were divided according to service process, including interview catalogue, book circulation and office, the person in charge of the three departments directly report to the curator .

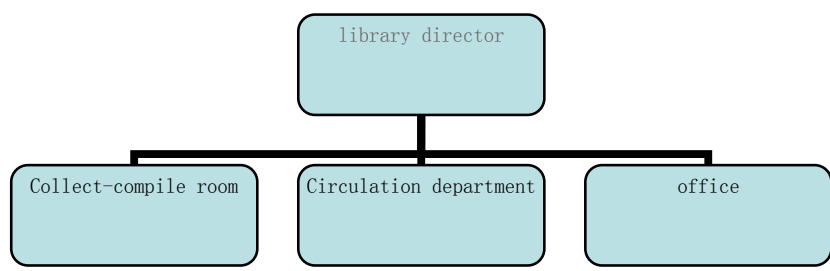

Fig. 1. Organization framework.

The second stage: With the development of military academies, the division of military disciplines began to be refined. Some of the larger military academies have begun to reconstruct. The library is divided into technical service, public service and development planning department. The technical service department includes interview, cataloging and continuous publication management. The public service department includes circulation, reference consultation, special collection and so on. The development planning department includes offices, human resources and accounting.

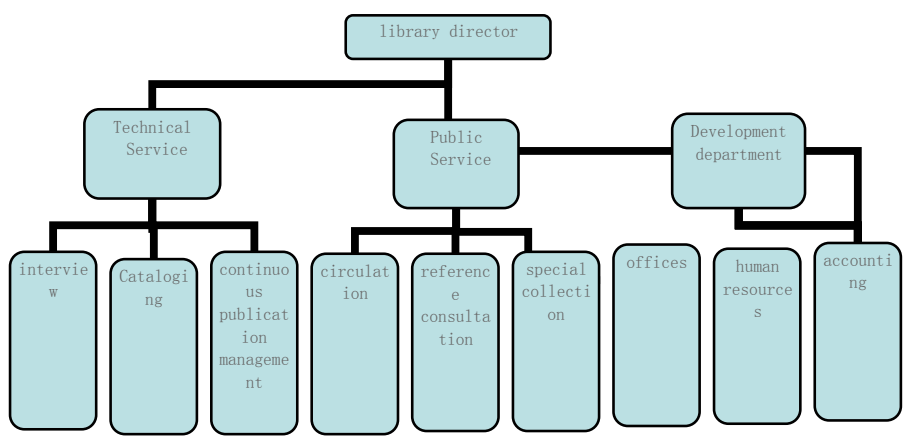

Fig. 2. Organization framework.

The third stage: Affected by new technology, academic communication and the reader's information demand and behavior all have greatly changed. People can get a lot of information from the Internet and Internet content providers, the library is no longer the only way for users to acquire knowledge and information .Facing the survival crisis, the university library had to work harder in business 
development, resources construction and service innovation. It also pay more attention to the change of the organization. Many libraries have established academic exchanges, learning support and research services based on the needs of the traditional collection development departments and technical service departments. Since the beginning of the 21 st century, the institutional settings of university libraries have shown the following characteristics: 1) traditional interviews, catalogue, circulation, reading and other departments present the characteristics of integration; 2) the periodical department presents a gradual reduction trend; 3 ) attaching importance to the setting up of the information advisory department and strengthening the consultation and training of teachers and students; 4) new business departments for developing multimedia and digital collections are added. But these are complementary to the existing organizational structure, and there is no qualitative change.

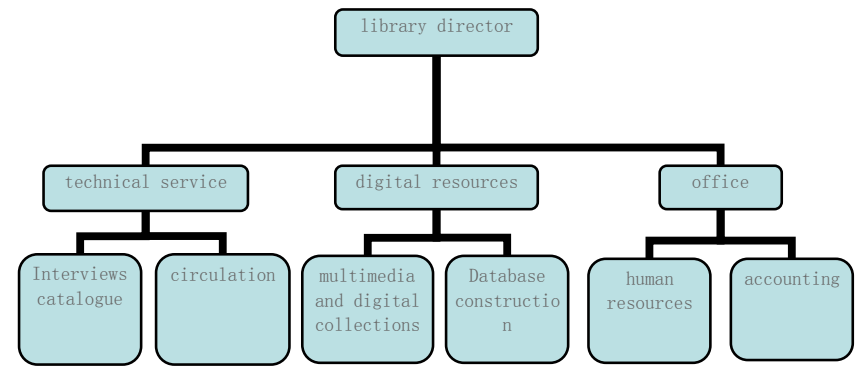

Fig. 3. Organization framework.

\section{THE NEW ROUND REFORM OF THE ARMY UNIVERSITIES PUT FORWARD NEW REQUIREMENTS TO THE LIBRARY}

With the change of the command system and the rapid development of weapons and equipment, the demand for military talent has changed greatly. The purpose of military academies reform is to enable military talent training mechanism adapts to this change, and provides continuous support for the strong army. In general, the reform of military academies is to compress quantity and improve quality, and set up a first-class military academies and firstclass military subjects with Chinese characteristics. As an important base for education, the library must adapt to the military reform requirements. The characteristics of the subject development under the background of the army reform are carefully studied, and the business work is carried out with innovative thinking and methods.

Relying on the information network, the library should strengthen the development and integration of information resources, improve the information sharing degree, satisfy the readers' increasing demand for information, and truly play an important role in modern teaching.

\section{THE BACKGROUND OF LIBRARY BUSINESS AND ORGANIZATION RESTRUCTURING}

\section{A. The Development and Change of Universities Requires the Library to Strengthen the Corresponding Resources}

The colleges structure has been adjusted because of military reform, basically formed the layout of joint operations colleges as the core and the troop professional institutions as the basis, the integration of military and civilian cultivation as the supplementary. The college subject development has also changed and presented some new features. Many universities set up new department and research institutions with unfamiliar subject, college teachers and students put forward information service requirements that related to these subjects, the library needs the corresponding professional academic resources to support the new discipline.

TABLE I. New Military ACADEMIES

\begin{tabular}{|l|l|}
\hline 1 & Smf command college of PLA \\
\hline 2 & Rocket Force University of Engineering \\
\hline 3 & Rocket Force College of Petty Officer \\
\hline 4 & Information Engineering University \\
\hline 5 & Chinese people's Liberation Army Special Warfare College \\
\hline 6 & $\begin{array}{l}\text { Chinese people's Liberation Army artillery Air Defense } \\
\text { Academy }\end{array}$ \\
\hline
\end{tabular}

B. The Reform of Education and Teaching Methods

Requires the Library to Provide the Corresponding Service

With the continuous development of universities reform, some changes have taken place in education. Military academies are transforming from academic education to professional education. Basic courses are centralized, special courses are diverted, and basic courses are jointly cultivated with local colleges. Such as flying cadets of Air Force Aviation University, their physics, English and other basic courses study at Tsinghua University, their flying majors return to Air Force Aviation University.

\section{The Development of Libraries and Related Fields Impel the Library to Accelerate the Transformation}

The change in digital publishing has been completed. The rapid development of network and information technology has been widely used in all fields. The book publication has changed greatly to digital publishing. The distribution of ebooks and electronic periodicals are different from that of traditional books and periodicals. There are more and more free resources and free networks to access.At the same time, readers' habit of reading and searching documents is changing. Teachers' and students' reading behaviors and reading ways continue to generate new characteristics. In my university,the survey result showed that: in 2017, online reading ratio reached $95 \%$, library reading ratio reached $92 \%$. The lend out data is on the downward trend and the digital resource browsing data is on the rise. Changing in reading habits requires the library to make adjustments in information collection to meet the readers ' needs. 
TABLE II. LEND OUT STATISTICS

\begin{tabular}{|l|l|}
\hline Years & Lend out \\
\hline 2013 & 75462 \\
\hline 2014 & 72159 \\
\hline 2015 & 43978 \\
\hline 2016 & 41028 \\
\hline 2017 & 33722 \\
\hline
\end{tabular}

TABLE III. ELECTRONIC RESOURCE CLICKING RATE

\begin{tabular}{|l|l|}
\hline Years & Electronic resource clicking rate \\
\hline 2013 & 187905 \\
\hline 2014 & 235604 \\
\hline 2015 & 300566 \\
\hline 2016 & 344210 \\
\hline 2017 & 397850 \\
\hline
\end{tabular}

From the perspective of Library's construction and service, the investment and service in paper resources has been decreasing year by year, the digital resources has been increasing rapidly instead, but human resources have been mostly invested in construction and service of paper resources. The above factors have brought challenges to the development of the library.

\section{Experience of University Libraries Restruction at Home and Abroad}

Since twenty-first Century, foreign university libraries have discussed for the service process re-engineering and service institutions reorganization. The University of California at Berkeley library released new organization chart in October 2015, in addition to the East Asian Library and Ben Kraft (Bancraft) library. The main organization include: collections, digital Initiatives \& Collaborative Services, educational Initiatives \& User Service Finance, Business \& Library Operations, Human Resource and development. The collection includes interviewing, archives, academic exchanges, project and policy analysis pieces, following and cooperation services including digital cataloging and meta-data service, library application and publishing, library computing infrastructure, inter-library service, remote education and library, including library service, user service in the user guide, arts and humanities, engineering and physics science, life and Health Sciences, social sciences etc.

The library business was organized in accordance with the information flow and the needs of the readers, also the subject service. At the same time, the library set up a Collection Services Council, the Public Services Council, the Cataloging \& Meta data Council, and several working groups: collection budget, academic exchanges, digital data, user experience experts, teaching experts. In collections department there are 40 Library Selectors, with the adjustment of library business, the organization name is adjusted at any time.

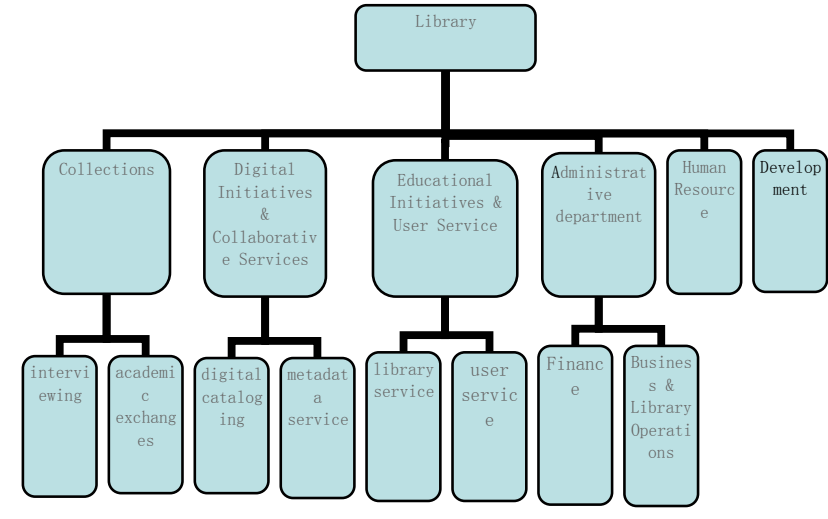

Fig. 4. Foreign university libraries Organization framework.

Peking University has introduced the idea of foreign university library to realize the goal of the world - class university library which included: strengthen the Internet thinking and deepen cooperation; adhere to the basic core value of library; integrate into teaching and scientific research; support open access and open publication, open education and open research, etc.

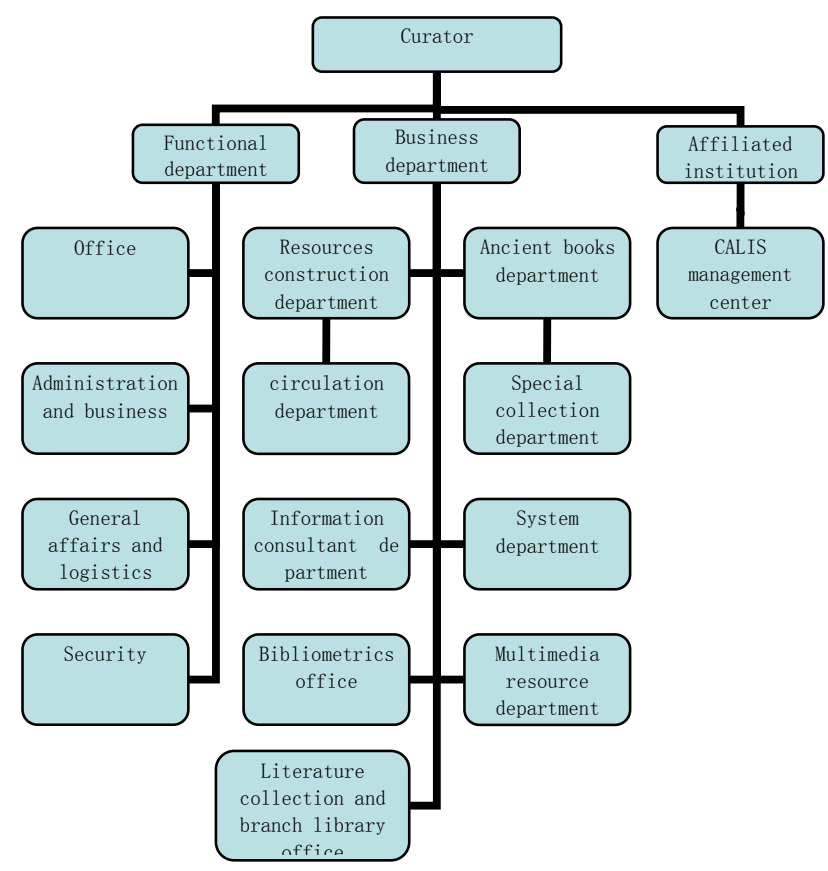

Fig. 5. Peking university libraries organization framework.

\section{LIBRARY INSTITUTION REORGANIZATION OF MILITARY ACADEMIES}

According to the role of the library in army construction, the library mainly considers the reorganization from three aspects: business work, teaching and scientific research and foreign relations. In business work, resource construction is the basis work of the library, including the collection, integration and revelation of literature resources. The 
construction of printed and digital resources is still important in library work; In teaching and research, the library provides all-round service for readers. For undergraduate students, the library provides book circulation service, writing instruction, multimedia and general retrieval and consulting services. For teachers and graduate students, the library provides topic consultations, research data services, subject service and other services. The library academic committee develops relevant rules and regulations to encourage librarians so they can devote to various scientific research projects. In the field of foreign relations, the development of the library cannot be separated from various foreign relations. In the field of university cooperation, the library needs to contact with the relevant units to obtain financial and material support. The library bears a heavy responsibility of building the system of literature and information resources. In domestic cooperation, the library should strengthen the cooperation with all kinds of Library alliances at all levels and fully realize the common knowledge and sharing of the literature resources.

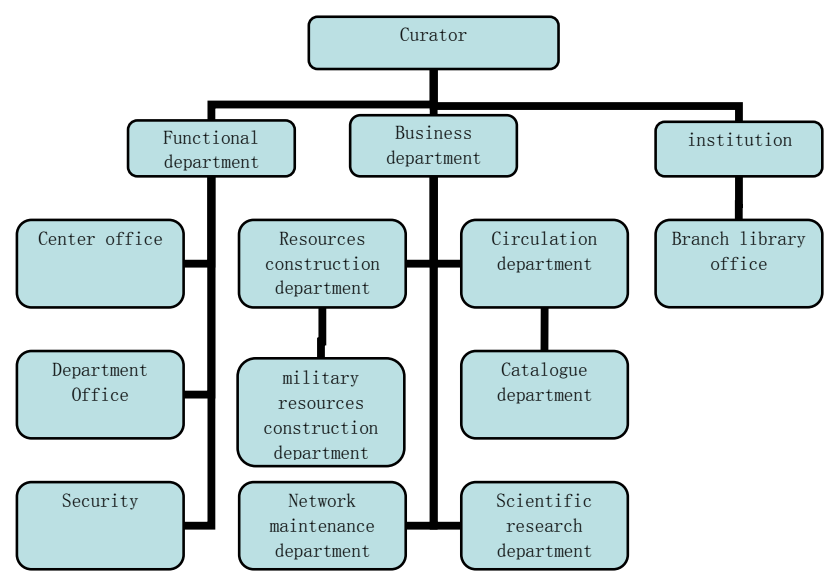

Fig. 6. Military university libraries organization framework.

\section{CONCLUSION}

The new organization will better adapt to the environmental change and users' habits change. As the new requirements brought by the library's own development, it will make the library play a greater role in serving the army's construction.

\section{REFERENCES}

[1] Li, X. (2014). What Would be the Future of the Integrated Library Systems? Proceedings of the IATUL Conferences. Paper 3. Retrieved 2 December 2014 from: http://docs.lib.purdue.edu/cgi/viewcontent.cgi?article=2042\&context =iatul.
[2] Brown, S. K., \& Burdsal, C. A. (2012). An exploration of sense of community and student success using the national survey of student engagement. Journal of GeneralEducation, 61(4), 433-460.

[3] Turner, A., Welch, B., \& Reynolds, S. (2013). Learning spaces in academic libraries-A review of the evolving trends. Australian Academic \& Research Libraries, 44(4),226-234. 